\title{
HUBUNGAN POLA ASUH ORANG TUA DENGAN PERILAKU SEKSUAL ANAK USIA REMAJA DI SMK N 1 TOMBARIRI
}

\author{
Indria M. Umboh \\ Adrian Umboh \\ Abram Babakal \\ Program Studi Ilmu Keperawatan Fakultas Kedokteran \\ Universitas Sam Ratulangi \\ Email : umbohindria@gmail.com
}

\begin{abstract}
Abstrack: Adolescence generally have a great sexual desires, so their feelings of fondness and love can turn into negative sexual desires and make them have sex before marriage which causes various advese effect such as pregnancy and the risk of numerous sexual transmitted diseases that lead to death so the right escort is needed here. One of the factors that influence sexual behaviour is parenting. The aim of this research is to know the relation between parenting and sexual behaviour of teens in SMK N 1 Tombariri. Research methods are using approach of cross sectional. This study involved 65 teens of grade XII as the respondents by using Total Sampling method. Data are collected by questionnaires. The Result is Pearson Chi Square with level of trust $95 \%(a, 0,05)$ which value of $p=0,022$ is smaller than $a=0,05$. Conclusion there is relation between parenting and sexual behaviour of teens in SMK N 1 Tombariri.
\end{abstract}

Keywords : parenting style, sexual behaviour, adolescents

Abstrak : Masa remaja umumnya terdapat dorongan seksual yang besar, sehingga perasaan suka dan cinta mereka dapat berubah menjadi nafsu seksual yang negatif yang membuat mereka melakukan hubungan seksual sebelum waktunya dan menimbulkan berbagai dampak buruk seperti kehamilan dan resiko berbagai penyakit menular seksual yang dapat berujung pada kematian, disinilah perlu pendampingan yamg tepat. Salah satu faktor yang mempengaruhi perilaku seksual adalah pola asuh orang tua. Tujuan penelitian ini adalah mengetahui hubungan pola asuh orang tua dengan perilaku seksual anak usia remaja di SMK N 1 Tombariri. Metode penelitian menggunakan pendekatan cross sectional. Responden terdiri dari 65 remaja kelas XII dengan teknik pengambilan sampel menggunakan Total Sampling. pengumpulan data menggunakan kuesioner. Hasil Uji Pearson Chi Square dengan tingkat kepercayaan 95\% (a $0,05)$, dimana nilai $p=0,022$ lebih kecil dari $a=0,05$. Kesimpulan ada hubungan antara pola asuh orang tua dengan perilaku seksual anak usia remaja di SMK N 1 Tombariri.

Kata kunci : pola asuh, perilaku seksual, anak usia remaja 


\section{PENDAHULUAN}

Remaja dalam bahasa Inggris disebut "adolescent" berasal dari bahasa latin yaitu "adolescere" yang berarti tumbuh ke arah kematangan. Kematangan itu bukan hanya kematangan fisik tetapi juga kematangan sosial dan psikologis. Masa remaja atau masa adolesens adalah suatu fase tumbuh kembang yang dinamis dalam kehidupan seorang individu (Surbakti, 2009). Anak usia remaja adalah harapan orang tua, bahkan dalam pandangan yang lebih luas, remaja adalah harapan negara. Karena sebagai generasi penerus, dalam tangan para remajalah terletak masa depan dunia. Oleh karena itu, setiap orang tua perlu mempersiapkan remaja, baik kematangan mental, emosi dan kedisiplinan sejak dini agar nantinya mereka siap untuk memegang tanggung jawab yang besar. Disinilah peran orang tua dalam keluarga yaitu pola asuh orang tua sangat diperlukan dalam mendidik dan membentuk karakter dan perilaku remaja,karena orang tua yang merupakan lingkungan terdekat sebelum mereka bersosialisasi dan bermasyarakat. Pola asuh orang tua merupakan salah satu aspek terpenting yang berarti turut membentuk perilaku dan karakter anak mereka. Sa'id (2017) menjelaskan faktor yang membuat seorang anak melakukan perilaku menyimpang adalah sikap orang tua yang buruk kepada anak.

Efendi, dkk (2009) menjelaskan masa remaja umumnya terdapat dorongan seksual yang besar, sehingga perasaan suka dan cinta mereka dapat berubah menjadi nafsu seksual yang negatif yang membuat mereka melakukan hubungan seksual sebelum waktunya, dorongan seksual sendiri adalah wajar dan tidak perlu ditakuti, dihindari atau di tekan tapi perlu pendampingan yang tepat sehingga tidak menimbulkan masalah. Peran orang tua untuk mengasuh remaja agar mereka tidak menyalahgunakan potensi seksual mereka untuk tujuan kesenangan belaka, dan menghindari remaja dari dampak yang paling sering timbul akibat penyimpangan perilaku seksual yaitu kehamilan dan penyakit menular seksual.

Centers for Disease Control and Prevention (CDC) menyebutkan bahwa pada tahun 2017, total 194.377 bayi dilahirkan dari wanita berusia 15-19 tahun, untuk tingkat kelahiran 18,8 per 1.000 wanita dalam kelompok usia ini dan survey yang dilakukan diantara siswa SMA di Amerika Serikat menunjukkan bahwa pada tahun 2016, hampir 210.000 bayi lahir dari remaja usia1 5-19 tahun. Survey Demografi dan Kesehatan Indonesia (SDKI, 2017) pada remaja di indonesia kehamilan tidak diinginkan karena pengalaman seksual dilaporkan oleh wanita kelompok umur 1519 tahun dua kali lebih besar (16\%) dibandingkan kelompok umur 20-24 tahun. Penularan penyakit menular seksual juga dapat terjadi akibat dari penyimpangan perilaku seksual anak usia remaja, yaitu terpaparnya berbagai penyakit yang dapat ditularkan melalui hubungan seksual seperti, hepatitis C, hepatitis B, Human Immuno-deficiency (HIV) dan berbagai infeksi menular seksual lainnya (CDC, 2015). Menurut Komisi Penanggulangan AIDS (KPA) Provinsi Sulawesi Utara, pada tahun 2013 Sebanyak 33 remaja di Sulawesi Utara mengidap HIV/AIDS pada rentang usia 15 sampai 19 tahun.

Putri dan Dewi (2015) menjelaskan ada beberapa faktor yang dapat mempengaruhi seorang remaja untuk melakukan hubungan seksual, faktor-faktor tersebut yaitu faktor religiusitas, faktor hubungan orang tua-remaja, dan faktor tekanan teman sebaya. Dari pernyataan diatas menyatakan salah satu faktor penting yang berhubungan dengan perilaku seksual adalah pola asuh orang tua. Kecenderungan perilaku seksual yang buruk dewasa ini salah satunya dipengaruhi oleh pola asuh orang tua yang salah dalam mengasuh dan membesarkan anak. Banyak orang tua tidak memberikan informasi mengenai seks dan kesehatan reproduksi kepada anaknya, karena takut hal tersebut justru akan meningkatkan terjadinya hubungan seks bebas di kalangan remaja. 
Hasil penelitian yang di lakukan oleh Farida (2013) pada remaja kelas XI di SMU Negeri yang ada di Kabupeten Karawang, disimpulkan bahwa salah satu penyebab perilaku seksual remaja adalah pola asuh orang tua yang juga disertai dengan pengetahuan dan status sosial ekonomi remaja.

Berdasarkan pendataan awal yang penulis peroleh di SMK N 1 Tombariri tercatat memiliki jumlah siswa keseluruhan 338 murid, dengan jumlah murid Kelas X 161 orang, Kelas XI 101 orang dan kels XII 77 orang. Dari wawancara singkat yang dilakukan peneliti kepada 9 orang murid, terdapat 7 pola asuh demokratis dan 2 pola asuh otoriter, 8 orang mengatakan melakukan perilaku seperti berpegangan tangan, kecupan pada pipi dan sentuhan kepada pasangan dan terdapat 1 orang mengatakan melakukan ciuman bibir kepada pasangan serta terdapat 3 murid yang hamil diluar nikah, 1 murid masih sempat mengikuti ujian akhir nasional dan 2 murid lainnya memutuskan tidak melanjutkan pendidikan mereka. Berdasarkan latar belakang di atas menunjukkan bahwa akan terjadi peningkatan perilaku seksual di kalangan anak usia remaja, maka dari itu penulis tertarik untuk meneliti mengenai hubungan pola asuh orang tua dengan perilaku seksual anak usia remaja di SMK Tombariri.

\section{METODE PENELITIAN}

Penelitian ini termasuk dalam jenis penelitian kuantitatif dengan menganalisis gambaran hubungan antara kedua variabel yaitu variabel independen (Pola asuh orang tua) dan variabel dependen (Perilaku seksual anak usia remaja). Penelitian ini menggunakan desain penelitian cross sectional. Penelitian ini dilaksanakan di SMK N 1 Tombariri pada tanggal 8 Januari 2019.Populasi penelitian ini adalah seluruh kelas IX dengan jumlah 77. Pengambilan sampel menggunakan teknik Total sampling maka didapatkan jumlah sampel yang memenuhi kriteria inklusi 65 sampel.
Instrumen penelitian yang digunakan untuk mengukur variabel pola asuh orang tua menggunakan kuesioner yang digunakan sebelumnya oleh Julia (2015) yang telah diuji validitasnya. kuesioner pola asuh menggunakan skala guttman yang terdiri dari dua alternatif jawaban dengan pembagian penilaian yaitu, skor 1 untuk jawaban "Ya" dan skor 0 untuk jawaban "Tidak". kuesioner ini terdiri dari 30 pertanyaan, 10 pernyataan untuk pola asuh Otoriter (pernyataan 1-10) , 10 pernyataan untuk pola asuh demokratis (pernyataan 1120) dan 10 pernyataan untuk pola asuh permisif (pernyataan 21-30). Setelah lembar kuesioner diisi oleh responden, kemudian dilakukan penghitungan skor dengan cara menjumlahkan skor tiap pertanyaan. Untuk menentukan jenis pola asuh yang diterapkan oleh orang tua dihitung dari jumlah skor tertinggi pada 3 jenis pola asuh tersebut.

Kuesioner untuk menilai perilaku seksual anak usia remaja ada 9 pernyataan yang dibuat oleh peneliti dan telah diuji validitas dan reliabilitas, kuesioner ini terdiri dari 9 pernyataan dengan alternatif pilihan jawaban Ya dan Tidak. Nilai bergerak dari 1 sampai 0 dimana pilihan Ya diberi skor 1 dan pilihan Tidak diberi skor 0 . Untuk mengukur perilaku seksual pada anak usia remaja ini dihitung jumlah cut of point dan didapatkan hasil dikatakan Beresiko : jika nilai responden > cut of point $(4,5)$, dan dikatan tidak beresiko : jika nilai responden < cut of point $(4,5)$.

Pengolahan data yang diperoleh dari hasil penelitian ini diolah secara manual dengan mengelompokkan hasil wawancara dan observasi kemudian dilakukan penghitungan skor dan dianalisis menggunakan uji statistik melalui sistem komuterisasi dengan beberapa tahap yaitu selecting, editing, coding, tranfering, tabulating. Analisa bivariat dalam penelitian ini yaitu untuk mengetahui hubungan pola asuh orang tua dengan perilaku seksual anak usia remaja di SMK N 1 Tombariri. Peneliti menggunakan uji 
statistic Pearson Chi-Squaredengan tingkat kemaknaan 95\% $(\alpha=0,05)$.

HASIL dan PEMBAHASAN

1. Karakteristik Responden

Tabel 1. Distribusi Sampel Berdasarkan Jenis Kelamin

\begin{tabular}{lll}
\hline Jenis Kelamin & $\mathbf{n}$ & $\mathbf{\%}$ \\
\hline Laki-laki & 39 & 60.0 \\
Perempuan & 26 & 40.0 \\
\hline \multicolumn{1}{c}{ Total } & $\mathbf{6 5}$ & $\mathbf{1 0 0 . 0}$
\end{tabular}

Sumber : Data Primer 2019

Hasil penelitian menunjukkan bahwa sebagian besar sampel memiliki jenis kelamin laki-laki sebanyak 39 orang dengan presentase $60,0 \%$. Mahmudah,dkk (2016) menjelaskan ada beberapa faktor yang dapat mempengaruhi perilaku seksual seorang remaja, salah satunya jenis kelamin. Hal ini didukung oleh penelitian yang dilakukan oleh Anniswah (2016) menyebutkan laki-laki lebih beresiko perilaku seksual dari pada perempuan, oleh karena itu anniswah melakukan penelitian tentang faktor-faktor yang mempengaruhi perilaku seksual beresiko IMS pada remaja pria yang dilakukan pada seluruh remaja pria indonesia. Mahmudah,dkk (2016) menjelaskan di kota Padang juga mengemukakan hal yang sama bahwa jenis kelamin laki-laki lebih beresiko memiliki perilaku seksual yang menyimpang. Terdapat aturan yang lebih longgar bagi remaja laki-laki dibandingkan dengan remaja perempuan, orang tua lebih protektif pada remaja perempuan dibandingkan pada remaja laki-laki. Remaja laki-laki cenderung lebih bebas dari remaja perempuan, sehingga dapat dipaham jika laki-laki memiliki peluang yang lebih besar untuk berperilaku seksual yang menyimpang dibanding perempuan.

\section{Analisa Univariat}

Tabel 2. Distribusi Sampel Berdasarkan Pola Asuh Orang Tua

\begin{tabular}{lll}
\hline Pola Asuh & $\mathbf{n}$ & \% \\
\hline Otoriter & 17 & 26.3 \\
Demokratis & 38 & 58.5 \\
Permisif & 10 & 15.4 \\
\hline Total & $\mathbf{6 5}$ & $\mathbf{1 0 0 . 0}$ \\
\hline
\end{tabular}

Sumber : Data Primer 2019

Hasil penelitian menunjukkan bahwa dari 65 sampel penelitian sebagian besar sampel mendapatkan pola asuh demokratis yaitu sebanyak 38 sampel $(58,5 \%)$ dan sisanya terdapat pola asuh otoriter 17 sampel $(26,2 \%)$ dan pola asuh permisif 10 sampel $(15,4 \%)$. Hal ini menunjukkan jenis pola asuh demokratis yang menjadi jenis pola asuh yang diterapkan oleh orang tua siswa di SMK N 1 Tombariri. Pola asuh Otoriter, pada jenis pola asuh ini, orang tua mengawasi perilaku anak dengan membuat aturan dalam keluarga yang tidak bisa dibantah atau harus dipatuhi. Pola asuh Permisif, orang tua akan membebaskan anak mereka dalam bertingkah laku untuk menghindari dari pemaksaan aturan-aturan dalam keluarga. Pada pola asuh demokratis, orang tua lebih mengarahkan anak untuk menyampaikan pendapat mereka tentang ketentuan dan peraturan yang ada dalam keluarga.

Penelitian yang dilakukan oleh Kartika dan Budisetyani (2018) menjelaskan pada remaja di denpasar dan badung menyimpulkan terdapat hubungan antara pola asuh demokratis orang tua dengan perilaku seksual remaja. Menurut kartika dan budisetyani, pada pola asuh demokratis, orang tua membuka komunikasi dengan anak dan menjalin keterbukaan di antara keluarga serta membimbing anak untuk berperilaku yang dapat dipertanggungjawabkan khususnya dalam perilaku seksual mereka, sehingga remaja tersebut juga tidak akan merasa ada jarak atau canggung serta tidak menutup- 
nutupi perilaku atau pengalaman seksual mereka kepada orang tua.

Berdasarkan hasil penelitian, beberapa teori dan hasil penelitian sebelumnya, Peneliti berasumsi bahwa orang tua siswa di SMK N 1 Tombariri menerapkan jenis pola asuh yang cocok dan baik untuk diterapkan kepada anak, didukung oleh hasil penelitian diatas yang menunjukkan jenis pola asuh yang menjadi dominan adalah pola asuh demokratis, dimana orang tua dengan, pola asuh demokratis ini lebih menunjukkan pengawasan yang kuat tetapi tetap disertai dengan dukungan dan pengertian kepada anak.

Tabel 3. Distribusi sampel berdasarkan Tipe Perilaku Seksual Anak Usia Remaja

\begin{tabular}{lll}
\hline Perilaku seksual & n & \% \\
\hline Beresiko & 23 & 35.4 \\
Tidak Beresiko & 42 & 64.6 \\
\hline Total & $\mathbf{6 5}$ & $\mathbf{1 0 0 . 0}$
\end{tabular}

Sumber : Data Primer 2019

Tabel 3 menunjukkan bahwa dari 65 sampel penelitian bahwa sebagian besar sampel memiliki perilaku seksual Tidak Beresiko yaitu sebanyak 42 responden $(64,6 \%)$ dan perilaku seksual Beresiko yaitu 23 responden (35,4\%). Hal ini menunjukkan jenis perilaku seksual yang lebih banyak pada siswa SMK $\mathrm{N} 1$ Tombariri adalah perilaku seksual yang tidak beresiko. Ada dua macam perilaku seksual manusia yaitu perilaku seksual yang beresiko dan perilaku seksual tidak beresiko. Pada jenis perilaku seksual tidak beresiko terdapat perilaku yang mungkin tidak disadari remaja kalau itu adalah salah satu bentuk perilaku seksual yaitu melihat pornografi, memikirkan seks dan seks lewat telepon/sms. Dari hasil penelitian diatas menunjukkan sebagian besar siswa di SMK $\mathrm{N} 1$ Tombariri hanya memiliki perilaku yang tidak menjurus pada dampak buruk dari perilaku seksual.
Berdasarkan hasil penelitian, teori, dan hasil penelitian sebelumnya, peneliti berasumsi bahwa remaja di SMK N 1 Tombariri memiliki perilaku seksual tidak beresiko, dibuktikan dengan hasil wawancara sebelumnya dengan siswa di SMK N 1 Tombariri mengatakan dimana sebagian besar hanya melakukan perilaku seperti berpegangan tangan. Berdasarkan juga dengan hasil observasi yang dilakukan peneliti didapatkan hasil jenis kelamin yang paling banyak adalah jenis kelamin laki-laki 39 responden $(60,0 \%)$ dan kelompok usia yang dominan adalah usia 17 tahun 34 responden $(52,3 \%)$ yang berada pada remaja akhir. Menurut Jahja (2011) menjelaskan pada remaja yang sudah berada pada masa remaja akhir, remaja sudah menemukan pendirian hidup dan mulai menjadi dewasa. Mereka sudah lebih berhati-hati dalam bersikap dan berperilaku, sehingga mereka lebih tau hal mana yang sebaiknya dilakukan dan tidak dilakukan serta dampak yang akan terjadi dari perilaku tersebut.

\section{Analisa Bivariat}

Tabel 4. Hubungan Pola Asuh Orang Tua dengan Perilaku Seksual Anak Usia Remaja di SMK N 1 Tombariri

\begin{tabular}{lcccc}
\hline Pola Asuh & \multicolumn{2}{c}{ Perilaku Seksual } & \multirow{2}{*}{ Total } & $\mathbf{P}$ \\
\cline { 2 - 3 } & \multicolumn{2}{c}{ Beresiko Tidak Beresiko } & & \\
\hline Otoriter & 3 & 14 & 17 & $\mathbf{0 . 0 2 2}$ \\
Demokratis & 13 & 25 & 38 & \\
Permisif & 7 & 3 & 10 & \\
\hline Total & $\mathbf{2 3}$ & $\mathbf{4 2}$ & $\mathbf{6 4}$
\end{tabular}

Sumber : Data Primer 2019

Tabel 4 hasil uji hipotesis dari pola asuh orang tua dengan perilaku seksual menggunakan uji statistik Pearson Chisquare pada tingkat kemaknaan 95\% $(\mathrm{a}=$ $0,05 \%)$, dari hasil penelitian yang telah dilakukan menunjukkan adanya hubungan antara pola asuh orang tua dengan perilaku seksual anak usia remaja di SMK N 1 Tombariri. Dimana nilai $\mathrm{P}=0,022$ lebih kecil dari $a=0,05$. Dengan demikian sesuai 
dengan dugaan awal penulis bahwa terdapat hubungan antara pola asuh orang tua dengan perilaku seksual anak usia remaja. Hasil penelitian ini didukung dengan penelitian yang dilakukan sebelumnya oleh Hargiyati, dkk (2016) dimana terdapat hubungan antara pola asuh orang tua dengan perilaku seks pranikah pada remaja usia (15-18) tahun di SMA X Kabupaten bandung.

Analisa hasil crosstab dengan menggunakan uji Pearson Chi-Square, penelitian untuk responden dengan pola asuh orang tua demokratis, memiliki perilaku seksual tidak beresiko sebanyak 25 responden dan perilaku seksual beresiko 13 responden. Hal ini terjadi karena adanya faktor lain yang dapat menyebabkan perilaku seksual beresiko pada remaja yaitu jenis kelamin. Berdasarkan hasil penelitian, responden yang berjenis kelamin laki-laki lebih banyak yakni 39 responden $(60,0 \%)$ dibanding perempuan yang hanya berjumlah 27 responden (40,0\%). Mahmudah, dkk (2016) menjelaskan Remaja laki-laki cenderung lebih bebas dari remaja perempuan, sehingga dapat dipaham jika laki-laki memiliki peluang yang lebih besar untuk berperilaku seksual yang menyimpang dibanding perempuan. Pada hasil crosstab juga menunjukkan terdapat perilaku seksual tidak beresiko 14 responden dan beresiko 3 responden pada pola asuh otoriter, menunjukkan bahwa perilaku seksual tidak beresiko yang lebih banyak dibanding perilaku seksual beresiko. Hal ini dikarenakan anak dengan penerapan pola asuh otoriter akan menjadi mudah dikontrol oleh orang tua, selain itu mereka akan cenderung menjadi kaku, sensitif pemalu bahkan tunduk, dikarenakan orang tua pada jenis otoriter ini mengawasi perilaku anak dengan membuat aturan dalam keluarga yang tidak bisa dibantah dan harus dipatuhi bahkan memiliki hukuman jika dilanggar (Wong, 2009).

Hasil crosstab pada pola asuh permisif memiliki perilaku seksual tidak beresiko sebanyak 3 responden dan beresiko sebanyak 7 responden, hal ini menunjukkan perilaku seksual beresiko yang paling banyak pada jenis pola asuh permisif ini, walaupun hanya memiliki jumlah total 7 dari 23 responden jumlah perilaku seksual beresiko, namun ini menunjukkan bahwa anak dengan penerapan pola asuh permisif juga dapat waspada pada perilaku seksual beresiko. Wong (2009) menjelaskan orang tua dengan jenis pola asuh permisif hanya membuat sedikit pengawasan bahkan tidak sama sekali pada anak, orang tua akan memberikan kebebasan pada anak dalam bertindak, hal ini yang dapat memicu seorang anak untuk secara bebas dalam berperilaku termasuk dalam perilaku seksualnya. Hasil crosstab pada pola asuh orang tua demokratis, memiliki perilaku seksual tidak beresiko sebanyak 25 responden dan perilaku seksual beresiko 13 responden dari jumlah total 38 responden. Hal ini menunjukkan anak dengan pola asuh demokratis lebih dominan pada perilaku seksual tidak beresiko. Dari hasil analisa tersebut peneliti berasumsi penerapan jenis pola asuh demokratis pada anak dapat membuat anak bertumbuh dan berkembang dengan baik, tidak tertekan dengan pengawasan yang kuat serta lebih terbuka dalam perilakunya sehari-hari, hal ini didukung oleh Wong (2009) menjelaskan orang tua yang menerapkan pola asuh jenis demokratis pada anaknya, lebih memberikan keterbukaan dan dukungan kepada anak serta membantu anak dalam pengarahan dirinya.

Asumsi peneliti, hasil penelitian dan beberapa teori, serta penelitian terkait yang menunjukan adanya hubungan yang signifikan antara pola asuh orang tua dan perilaku seksual anak usia remaja. Hal ini didukung oleh penelitian yang dilakukan oleh Fatimah, dkk (2013) menyebutkan pada siswa SMK di Surakarta didapat hasil ada hubungan antara pola asuh orang tua dengan perilaku seksual pada remaja, peneliti juga berasumsi ada hubungan yang signifikan antara pola asuh orang tua dengan perilaku seksual anak usia remaja serta memiliki hubungan sebab akibat hal 
ini dikarenakan orang tua merupakan faktor internal dari penentuan perilaku seorang anak. Perlakuan dan sikap yang buruk dari orang tua dapat menyebabkan perilaku seksual yang menyimpang pada anak, Sa'id (2017).

Berdasarkan pembahasan diatas, dapat disimpulkan bahwa perilaku seksual yang tidak menyimpang bisa didapat jika pola pengasuhan orang tua tepat pada anak. Pola asuh orang tua yang tepat adalah pola asuh demokratis, karena pada pola pengasuhan demokratis orang tua lebih berfikir rasional dan memberikan kesempatan pada anak untuk bisa berperilaku yang baik dan sesuai dengan kemauan anak namun tetap diawasi oleh orang tua. Hal ini didukung oleh penelitian yang dilakukan oleh kartika dan budisetyawan (2016) menjelaskan pola asuh demokratis memiliki hubungan dengan perilaku seksual pranikah remaja dimana remaja dengan pola asuh demokratis akan meniru orangtuanya dalam hal komunikasi terbuka sehingga menurunkan perilaku seksual pranikah yang beresiko buruk bagi masa depan mereka.

\section{SIMPULAN}

Faktor yang mempengaruhi perilaku seksual anak usia remaja adalah pola asuh orang tua. Orang tua memiliki berbagai cara mengasuh dan mendidik anak mereka. Ada 3 bentuk pola asuh yang dapat digunakan orang tua yaitu pola asuh otoriter, demokratis, dan permisif. Dalam penelitian ini, orang tua menerapkan pola asuh demokratis dalam mendidik anak mereka. Pola asuh demokratis yang diberikan orang tua dapat memberikan dampak yang baik kepada perilaku anak khususnya pada perilaku seksual mereka. Pada penelitian ini, terdapat 2 jenis perilaku seksual remaja, yaitu beresiko dan tidak beresiko.

\section{DAFTAR PUSTAKA}

Anniswah, N. 2016. Faktor-faktor yang berhubungan dengan perilaku seksual beresiko IMS pada remaja pria di indonesia. Universitas Islam Negeri Syarif Hidayahtullah. Jakarta

Center for Disease Control and Prevention (CDC). 2015. Adolescent and School Health: Sexual Risk Behaviors: HIV, STD, \& Teen Pregnancy Prevention. Diperoleh dari https://www.cdc.gov/healthyyouth/se xualbehaviors/ pada tanggal 31 September 2018

Efendi, Ferry., Makhfudli. 2009. Keperawatan Kesehatan Komunitas: Teori dan praktik dalam keperawatan. Jakarta: Salemba Medika.

Evayanti, Y. 2012. Pengaruh Faktor Individu dan Orang Tua Terhadap Perilaku Seks Pranikah yang Beresiko Kehamilan Tidak Diinginkan pada Remaja Sekolah Menengah Umum Se-Kecamatan Bukit Kemuning Lampung Utara Tahun 2011. Fakultas Kedokteran Universitas Malahayati. Lampung

Farida, Y. 2013. Hubungan Pengetahuan, Status Sosial Ekonomi, Pola Asuh Orang Tua, Paparan Media Pornografi dengan perilaku seksual remaja di SMU Negeri Kabupaten Karawang. Bandung; Poltekes Kemenkes Bandung

Fatimah, N. Hidayah, N. Maryatun. 2013. Hubungan Antara Pola Asuh Orang Tua dengan Perilaku Seksual Pranikah Pada Remaja di SMK Batik 1 Surakarta. Sekolah tinggi ilmu kesehatan 'Aisyiyah Surakarta

Jahja, Y. 2011. Psikologi Perkembangan. Prenadamedia Group: Jakarta

Julia, J, M. 2015. Hubungan Antara Pola Asuh Orang Tua dengan Kebiasaan Merokok Anak Usia Remaja 12-17 Tahun di Desa Kilometer Tiga 
e-journal Keperawatan(e-Kp) Volume 7 Nomor 1, Mei 2019

Kecamatan Amurang. Universitas Sam Ratulangi. Manado

Kartika, D. Budisetyani, P, W. 2018. Hubungan pola asuh demokratis dengan perilaku seksual pranikah pada remaja di denpasar dan badung. Universitas Udayana. Denpasar

Mahmudah, Yaunin Y, Lestari Y. 2016. Faktor-faktor yang berhubungan dengan perilaku seksual remaja di kota padang. Universitas Andalas. Padang

Putri, D, H. Dewi, K, S. 2015. Analisis faktor-faktor yang mempengaruhi perilaku seksual pranikah remaja diSMA $N 2$ Ungaran. Universitas diponegoro. Semarang.

Sa'id, M, A. 2017. Buku Pintar Mendidik Remaja. Semesta Hikmah: Prambanan Klaten

Surbakti, E, B. 2009. Kenalilah Anak Remaja Anda. PT Alex Media Komputindo: Jakarta. E-book di akses di https://books.google.co.id/

Survey Demografi dan Kesehatan Indonesia (SDKI). 2017. Buku Remaja: Kehamilan yang Tidak diinginkan. https://cis.bkkbn.go.id 29 Oktober 2018

Wong, D . L. (2009). Buku Ajar Keperawatan Pediatric. Edisi 6. Volume 1. Jakarta: EGC 